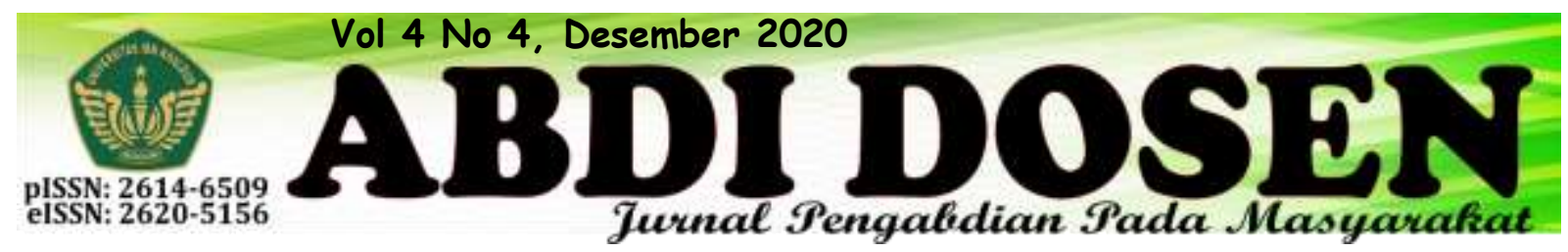

\title{
MENINGKATKAN KETERAMPILAN DAN POTENSI MASYARAKAT MELALUI PEMBERDAYAAN MASYARAKAT
}

\author{
Setya Permana Sutisna ${ }^{1}$ dan Siti Khodijah Parinduri ${ }^{2}$ \\ setya.permana@uika-bogor.ac.id ${ }^{1}$ \\ sikho.parinduri@gmail.com ${ }^{2}$ \\ Dosen Fakultas Agama Islam ${ }^{1}$, Dosen Fakultas Ilmu Kesehatan ${ }^{3}$
}

\begin{abstract}
ABSTRAK
Mahasiswa sebagai agen perubahan memiliki tanggungjawab yang besar untuk bisa memberikan manfaat bagi masyarakat dan lingkungannya. Salah satu kegiatan yang bisa dilakukan adalah melakukan pemberdayaan masyarakat. Kegiatan ini dilakukan dengan metode sosialisasi, pemberian edukasi, praktek dan pemberian fasilitas. Pelaksanaan KKN dimulai dari tanggal 6 Agustus 2019 sampai dengan 6 September 2019 di Desa Wangunjaya Kecamatan Leuwisadeng Kabupaten Bogor. Program KKN kelompok 35 dan 36 di Desa Wangun Jaya merupakan program yang lebih menekankan kepada Kualitas Sumber Daya dan Mutu Pendidikan. Kegiatan fisik kelompok 35 dan 36 yaitu pemberian dan pemasangan papan nama jalan, pembuatan Gardu Desa dan pembuatan alat pembakar sampah (Incinerator). Dan kegiatan non fisik kelompok 35 dan 36 antara lain Cek Kesehatan Gratis, Penyuluhan Cuci Tangan yang Baik dan Benar, Jum'at Bersih, Bimbingan Belajar, Pelatihan Komputer Dasar (MS. Office dan MS Excel), Penyuluhan Tabungan Dini, Kewirausahaan, Pelaksanaan kegiatan TPA, Lomba 17 Agustusan, dan Panggung Gembira.
\end{abstract}

\section{Kata Kunci : Masyarakat, Pemberdayaan Masyarakat, Program KKN}

\section{PENDAHULUAN}

Mahasiswa sebagai agent of change yaitu mahasiswa memiliki peran sebagai agen yang membawa perubahan dalam berbagai bidang yang digelutinya untuk menjadikan bangsa dan negara lebih baik. Oleh sebab itu mahasiswa memiliki tanggungjawab yang besar untuk bisa bermanfaat dalam masyarakat dan juga lingkungannya (Sutrisman, 2019).

Hadirnya sebuah perguruan tinggi memerlukan masyarakat dan masyarakat memerlukan perguruan tinggi. Dalam hal ini, masyarakat akademik khususnya para mahasiswa mempunyai kesempatan langsung dalam pembangunan pemberdayaan masyarakat (Syarifudin,
2012). Menurut Riadi (2017), pemberdayaan masyarakat adalah menambah atau menguatkan kemampuan masyarakat agar lebih mandiri sehingga mampu mencukupi kebutuhan hidupnya baik bersifat sosial, fisik maupun ekonomi.

Pengabdian kepada masyarakat melalui KKN memiliki manfaat besar bagi mahasiswa untuk meningkatkan kualitas diri agar terus termotivasi dan berinovasi untuk perubahan yang lebih baik dimasa mendatang. Melalui KKN ini juga dapat memberikan pengalaman belajar dan bekerja kepada mahasiswa dalam kegiatan pembangunan masyarakat sebagai wahana 
penerapan dan pengembangan ilmu yang telah didapatkan

Menurut Direktorat Pembinaan Penelitian dan Pemberdayaan Masyarakat (2007), Kuliah Kerja Nyata (KKN) merupakan suatu bentuk program yang mengintegrasikan secara menyeluruh ilmu yang dipelajari dan dimiliki oleh mahasiswa. Kemudian ilmu tersebut disalurkan dan diwujudkan dalam bentuk nyata dengan memadukan pelaksanaan Tri Darma Perguruan Tinggi (pendidikan, penelitian, dan pengabdian kepada masyarakat).

Kuliah Kerja Nyata (KKN) yang dilakukan mahasiswa Universitas Ibn Khaldun Bogor merupakan program wajib yang diikuti seluruh mahasiswa sebagai bentuk pengabdian kepada masyarakat sebagai wadah untuk berpartisipasi dalam membangun desa-desa melalui pemberdayaan masyarakat pada segala bidang. Baik itu dalam bidang pendidikan, hukum, ekonomi, kesehatan, agama islam dan teknik.

\section{Gambaran Umum Wilayah}

Berdasarkan hasil observasi dan analisis yang kelompok kami lakukan di Desa Wangunjaya Kecamatan Leuwisadeng Kabupaten Bogor - Jawa Barat. Desa Wangunjaya memiliki luas wilayah 301,76 ha. Memiliki ketinggian dari permukaan laut setinggi $101-500$ mdpl. Curah hujan setinggi 2500 - 3000 $\mathrm{mm} / \mathrm{th}$. Bentuk wilayahnya yaitu dataran berbukit dengan kemiringan 5-20 derajat.

\section{Batas Wilayah}

Dengan batas wilayah sebagai berikut:

Sebelah Utara: Desa Babakansadeng Kec. Leuwisadeng.

Sebelah Selatan: Desa Bantarkaret - Kec. Nanggung

Sebelah Barat: Tanah Kehutanan
Sebelah Timur: Desa Sadengkolot Kec. Leuwisadeng

\section{Kependudukan}

Desa ini terdiri dari 5 Dusun, 11 RT dan 40 RW. Jumlah Penduduk Desa Wangunjaya Tercatat sebanyak: 7.891 jiwa, terdiri dari laki-laki: 4.098 jiwa dan perempuan: 3.793 jiwa dan jumlah Kepala Keluarga: 2.104 Kepala Keluarga. Secara rinci klasifikasi penduduk. Mata pencaharian masyarakata Desa Wangunjaya yaitu Pegawai Negeri Sipil, Pemilik Tanah, Petani, Buruh, Pengusaha, Pengrajin, Pedagang dan Pengemudi.

\section{Kesehatan}

Adapun prasarana kesehatan di Desa Wangunjaya terdapat Bidan Desa sebanyak 1 buah, Puskesmas Pembantu sebanyak 1 buah dan posyandu sebanyak 11 buah.

Adapun hasil dari observasi kelompok kami bahwa Di desa Wangunjaya sendiri, cukup banyak masyarakatnya yang belum terampil mengolah sampah, terutama limbah rumah tangga yang didominasi oleh plastik. Hal ini menimbulkan banyaknya timbunan sampah di saluran air warga yang pada saat musim penghujan menjadi penyebab melubernya air hujan ke jalan. Melihat masalah ini, kami berinisiatif untuk membuat incinerator. Incinerator merupakan sebuah alat untuk membakar sampah dengan menggunakan suhu yang sangat tinggi sehingga hasil akhir setelah pembakaran adalah abu (Chandra, 2009). Alat ini sangat membantu untuk menanggulangi masalah penumpukan sampah terutama untuk sampah plastik. Pembuatan Alat Pembakar Sampah (Incinerator) tersebut dirangkai di UIKA oleh mahasiswa fakultas teknik dan dibantu oleh mahasiswa lainnya. Kemudian pada tanggal 1 September 2019 dilakukan uji coba dan sosialisasi 
bagaimana cara menggunakan incinerator tersebut yang dilakukan di Desa Wangunjaya kepada masyarakat. Setelah dipastikan berfungsi, alat tersebut di hibahkan kepada masyarakat Wangunjaya melalui Desa.

Adapun masalah lain di Desa Wangunjaya yaitu :

- Kurangnya kesadaran akan pentingnya pendidikan.
- Kurangnya pengetahuan tentang kesehatan, terutama dalam hal sanitasi dan penyakit tidak menular.

- Kurangnya kemandirian masyarakat terkait perekonomian

- Kurangnya pengetahuan mengenai teknologi

- Kurangnya kesadaran akan dampak kenakalan remaja

- Kurangnya pengetahuan tentang dampak sampah bagi lingkungan, khususnya sampah plastik.

\section{METODE}

Metode yang kami gunakan untuk program unggulan kami yaitu dengan Metode Participatory Learning and Action (PLA)

Metode pelaksanaan pemberdayaan masyarakat menggunakan Participatory Learning and Action (PLA) merupakan metode pemberdayaan dengan melibatkan masyarakat yang terdiri dari proses belajar sambil bekerja (Ibnouf dkk, 2015) yaitu mengadakan alat pembakar sampah (incinerator) agar warga lebih mudah dalam mengelola sampah padat mereka. Tahapan kegiatan pengabdian yang dilakukan dengan metode $P L A$, sebagai berikut:

1) Analisis situasi, pada tahap ini kelompok KKN 35 dan 36 menguraikan potensi, nilai strategis, kondisi sosial, dan ekonomi, serta permasalahan Desa Wangunjaya berdasarkan data dan informasi dari Kepala Desa, RT, RW, dan masyarakat. Diperlukan partisipasi Kepala Desa Wangunjaya, RT, RW, dan masyarakat untuk dapat secara terbuka memberikan informasi guna penentuan akar dari permasalahan yang dihadapi.

2) Rancang pembuatan alat incinerator, pada tahap ini kelompok KKN 35 dan 36 mahasiswa dan perguruan tinggi bekerja sama merancang agar alat tersebut dapat disesuaikan dengan kebutuhan masyarakat untuk pengelolaan sampah di Desa Wangunjaya. Dan melibatkan masyarakat langsung dalam proses penggunaannya.

\begin{tabular}{|c|c|c|c|}
\hline No. & $\begin{array}{l}\text { Tahap } \\
\text { Pelaksanaan }\end{array}$ & Metode & Hal yang diharapkan \\
\hline 1 & Pendidikan & $\begin{array}{ll}\text { - } & \text { Sosialisasi } \\
\text { - } & \text { Pemberian } \\
& \text { edukasi }\end{array}$ & $\begin{array}{l}\text { - } \text { Meningkatkan kesadaran tentang } \\
\text { pentingnya pendidikan untuk masa } \\
\text { depan } \\
\text { - Dapat meningkatkan motivasi anak- } \\
\text { anak untuk belajar }\end{array}$ \\
\hline 2 & Ekonomi & $\begin{array}{ll}- & \text { Sosialisasi } \\
\text { - } & \text { Pemberian }\end{array}$ & $\begin{array}{l}\text { - Meningkatkan kemandirian masyarakat } \\
\text { dalam aspek perekonomian }\end{array}$ \\
\hline
\end{tabular}




\begin{tabular}{|c|c|c|c|}
\hline & & $\begin{array}{ll} & \text { edukasi } \\
\text { - } & \text { Pemberian } \\
& \text { Fasilitas } \\
\text { - } & \text { Praktek }\end{array}$ & 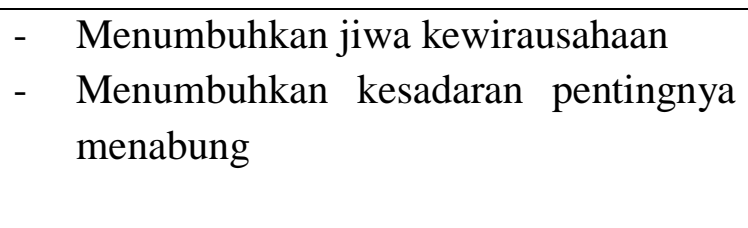 \\
\hline 3 & Hukum & - $\quad$ Sosialisasi & $\begin{array}{l}\text { - Siswa dapat memahami pengertian } \\
\text { kenakalan remaja dari sudut pandang } \\
\text { hukum } \\
\text { - Siswa mengetahui faktor-faktor } \\
\text { penyebab kenakalan remaja } \\
\text { - Siswa mampu mengetahui solusi } \\
\text { dalam mengatasi kenakalan remaja }\end{array}$ \\
\hline 4 & Kesehatan & $\begin{array}{ll}- & \text { Sosialisasi } \\
- & \text { Pemberian } \\
& \text { edukasi } \\
- & \text { Pemberian } \\
& \text { Fasilitas }\end{array}$ & $\begin{array}{ll}\text { - } & \text { Mempromosikan kesehatan } \\
\text { - } & \text { Meningkatkan kesadaran masyarakat } \\
\text { terhadapat kesehatan } \\
\text { - } \\
\text { Mencegah terjadinya penyakit di } \\
\text { masyarakat }\end{array}$ \\
\hline 5 & Agama Islam & 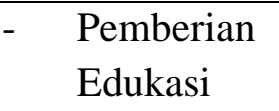 & $\begin{array}{l}\text { - Memberikan edukasi seperti ilmu baca } \\
\text { tulis Alqur'an dan ilmu agama islam }\end{array}$ \\
\hline 6 & Teknik & $\begin{array}{ll} & \text { Sosialisasi } \\
\text { - } & \text { Pemberian } \\
& \text { Edukasi } \\
- & \text { Pemberian } \\
& \text { Fasilitas }\end{array}$ & $\begin{array}{lll}\text { - } & \text { Memberikan pengetahuan dasar } \\
\text { tentang komputer } & \\
\text { - } & \text { Memberikan informasi dan tanda } \\
& \text { lokasi pada alamat terntentu. }\end{array}$ \\
\hline
\end{tabular}

\section{REALISASI PROGRAM}

\section{a. Bidang Pendidikan}

- Bantuan Mengajar di SD dan PAUD

Kegiatan mengajar di SD dilaksanakan setiap hari Senin - Sabtu pukul 10.00 s/d 12.30 WIB di Sekolah MI Pui Darul Awwalin adapun mata pelajaran yang ajarkan yaitu B.Inggris, Matematika, Fiqih, B.Arab, Aqidah Akhlak, Al Qur'an dan Hadist, dan PJOK) adapun yang diajarkan yaitu kelas 4 dan 5 MI.

Dan membantu mengajar di PAUD Cahaya di laksanakan setiap hari Senin Kamis jam 09.00 s/d 11.00 WIB terdapat 30 siswa di PAUD tersebut.

\section{- Bimbingan Belajar}

Kegiatan Bimbingan belajar dilaksanakan setiap hari Selasa - Jum'at, pelajaran yang di ajarkan yaitu
Matematika, B.Inggris dan baca tulis AlQur'an, dan bimbingan belajar dilaksanakan di posko kelompok 35 \& 36 . Jumlah anak yang mengikuti bimbingan belajar yaitu sekitar 20 orang, terdapat siswa SD, SMP, dan SMK. Adapun tujuan diadakan bimbingan belajar yaitu membantu anak-anak murid yang kesulitan memahami pelajaran dan membantu mengerjakan pekerjaan rumah anak - anak murid tersebut.

\section{b. Bidang Ekonomi}

- Kewirausahaan "Pelatihan Pembuatan Bros"

Kegiatan Pelatihan Pembuatan Bros ini dilaksanakan di majelis ta'lim warga Kampung Cisaranten 2 dengan peserta yaitu ibu - ibu warga sekitar. Kegiatan ini 
dilaksanakan pada pukul 10.00 s/d 11.00 WIB

\section{- Celengan Kreasi}

Menabung adalah proses menyisihkan sebagian uang dan disimpan hingga ketika membutuhkannya. Hal tersebut perlu diterapkan kepada anak-anak agar mereka mulai bisa mengatur keuangannya sendiri. Kegiatan celengan kreasi bisa menjadi salah satu alternatif untuk menarik perhatian anak-anak untuk menabung. Celengan kreasi ialah membuat sebuah celengan yang biasa menjadi lebih unik atau lebih menarik. Membuat celengan kreasi ini dilakukan bertujuan untuk mensosialisasikan tentang pentingnya menabung sejak usia dini. Kegiatan ini juga berfungsi untuk menjelaskan manfaat dari menabung usia dini sehingga dapat memotivasi anak-anak dalam menabung. Sosialisasi kegiatan ini dilakukan pada tanggal 21 Agustus 2019 kepada kelas 5 di MI Pui Darul Awwalin. Anak-anak diberikan snack-snack sebagai modal usaha awal mereka, lalu kemudian mereka menjualnya. Keuntungan yang mereka hasilkan lalu dimasukkan kedalam celengan kreasi yang telah mereka buat. Selanjutnya pada tanggal 4 September 2019 kami memberikan hadiah kepada seluruh kelompok yang telah berpartisipasi.

\section{c. Bidang Hukum}

- Seminar Hukum

Kegiatan. Seminar Hukum ini bertemakan "Kesadaran Hukum Generasi Milenial Akan Bahayanya Kenakalan Remaja" dilaksanakan pada tanggal 26 Agustus 2019 di Aula Kecamatan Leuwisadeng pada pukul $10.00 \mathrm{~s} / \mathrm{d}$ selesai adapun sasaran seminar hukum ini yaitu 40 siswa/siswi yang terdiri dari 4 sekolah menengah atas di Kecamatan Leuwisadeng, serta para guru yang mendampingi siswa/siswi yang bertujuan untuk mensosialisasikan tentang bahaya kenakalan remaja dan apa saja pencegahaan yang dapat dilakukan.

\section{d. Bidang Kesehatan}

- Cek Kesehatan Gratis

Kegiatan cek kesehatan gratis ini dilaksanakan pada tanggal 21 Agutus 2019 pukul 10.00 s/d selesai. Kegiatan ini di tujukan untuk warga usia produktif. Kegiatan inipun dilaksanakan dengan melakukan kerjasama dengan Puskesmas Sadeng Pasar yang mempunyai wilayah kerja di Desa Wangunjaya, kegiatan ini bertujuan untuk melakukan screening penyakit tidak menular yang diderita oleh masyarakat Desa Wangunjaya.

- Penyuluhan Cuci Tangan

Kegiatan ini dilaksanakan pada tanggal 28 Agutus 2019 di MI PUI AnNuriyah Desa Wangunjaya pada pukul $10.00 \mathrm{~s} / \mathrm{d}$ selesai, dengan peserta yaitu siswa/siswi kelas 3 \& 4, dengan tujuan mensosialisasikan cara mencuci tangan dengan baik dan benar kepada siswa dan siswi tersebut. Kami pun memberikan fasilitas seperti handsanitizer untuk sekolah dan beberapa poster kesehatan untuk dipasang di sekitar sekolah untuk mempromosikan kesehatan warga sekolah tersebut.

\section{- Penyuluhan Stunting}

Kegiatan ini dilaksanakan pada tanggal 30 Agustus 2019 pada pukul 19.00 s/d selesai bertempat di Majlis Ta'lim Pondok Pesantren Nurussibyan Kp Cisaranten 2 Desa Wangunjaya. Penyuluhan dilakukan langsung oleh Dosen dari Fakultas Ilmu Kesehatan Universitas Ibn Khaldun Bogor. Yang sasarannya yaitu remaja putri Desa Wangunjaya.

\section{e. Bidang Agama Islam}

- Partisipasi Pengajian Majlis Ta’lim 
Kegiatan pengajian di ikuti oleh mahasiswa KKN secara rutin dilaksanakan setiap hari Rabu pukul 08.00 s/d selesai. Pengajian ini diselenggarakan oleh ibu-ibu dan bapak-bapak di Desa Wangunjaya, dengan susunan kegiatan yaitu membaca solawat, berdo'a bersama dan mengkaji ilmu fiqih setiap pertemuannya.

- Mengajar Baca Al-Qur'an

Kegiatan ini dilaksanakan rutin setiap hari di pondok pesantren sekitar Desa, pada pukul 18.00 s/d 19.00 WIB. Mahasiswa KKN ikut berkontribusi dalam mengajar anak-anak Desa yang belum bisa membaca Al-Qur'an dengan baik dan benar.

\section{- Pengajian Rutin Remaja}

Kegiatan pengajian remaja ini dilaksanakan di mushola sekitar posko KKN 35 \& 36 Desa Wangunjaya, terdapat remaja pondok pesantren sekitar mushola yang mengikuti pengajian tersebut yaitu sekitar 30 santri. Pengajian ini dilaksanakan setiap hari selasa - jum'at pada pukul 19.30 s/d 20.00 WIB. Yang diisi kajiannya oleh mahasiswa dari fakultas agama islam. Adapun yang dikaji dalam pengajian ini adalah mempelajari qiro'ati dan memberikan tausiyah.

\section{f. Bidang Teknik}

- Pelatihan Komputer Dasar

Kegiatan pelatihan komputer dasar dilaksanakan di Kantor Desa dan posko kelompok KKN 35 \& 36. Adapun yang menjadi peserta pelatihan yaitu siswa/siswi Sekolah Dasar dan SMP, Kegiatan ini bertujuan untuk melatih siswa/siswi sekitar Desa untuk dapat menggunakan Microsoft Word dan Microsoft Excel.
- Pembuatan Gapura

Adapun Program kerja pembuatan gapura Desa WangunJaya yang bertuliskan Selamat Datang dan Selamat Jalan yang ditempatkan di batas jalan desa.

\section{g. Program Unggulan Lainnya}

- Santunan Anak Yatim

$\begin{array}{rrr}\text { Sebagai seorang muslim yang } \\ \text { berkecukupan, } & \text { kita } & \text { berkewajiban }\end{array}$ menanggung saudara-saudara kita yang kurang mampu. Diantaranya fakir, miskin dan anak yatim. Dan karena bertepatan dengan bulan Muharam dimana bulan Muharam disebut sebagai Hari Rayanya anak yatim, maka kami mengadakan santunan anak yatim, yang kami bagikan langsung kepada anak yatim di Desa Wangunjaya.

- Bakti Sosial

Kegiatan ini dilaksanakan pada tanggal 1 September 2019 pada pukul $09.00 \mathrm{~s} / \mathrm{d}$ selesai . Bakti sosial diadakan untuk memberikan baju layak pakai kepada ibu-ibu sekitar Desa Wangunjaya khususnya RT 01/08 . Pakaian itu diharapkan bisa digunakan untuk kebutuhan sehari-hari, seperti ke kebun, ke sawah, bahkan dipakai sehari-hari.

- Panggung Gembira

Kegiatan ini dilaksanakan pada tanggal 4 September 2019 pukul 16.00 s/d selesai. Panggung gembira diadakan untuk acara penutupan KKN kelompok $35 \& 36$, yang menampilkan kreatifitas anak-anak Desa Wangunjaya. Selain itu, panggung gembira dimaksudkan untuk memberikan hiburan kepada warga sekitar. Kegiatan ini pun bekerjasama dengan karang taruna Desa Wangunjaya. 


\section{KESIMPULAN}

Ada beberapa bidang yang kami buat yaitu bidang pendidikan, ekonomi, kesehatan, hukum, agama islam, dan teknik. Bidang - bidang ini kami bagi rata dalam pengambilan tanggungjawabnya. Sehingga memudahkan kami dalam membuat suatu program dan menjalankannya. Dari Kuliah Kerja Nyata ini kami menyimpulkan bahwa pelaksanaan KKN ini dapat dikatakan berhasil dan lancar. Adapun keberhasilan dan kelancaran ini adalah hasil dari kerjasama antar mahasiswa dan semua aparat serta masyarakat desa yang sudah membantu dan mendukung kegiatan KKN ini, sehingga program $\mathrm{KKN}$ ini dapat membantu masyarakat sekitar. Dari Adanya KKN kegiatan yang telah kami lakukan dalam beberapa bidang terdapat peningkatan yang terjadi untuk pemberdayaan masyarakat dan juga memberikan dampak besar terhadap masyarakat Desa sedikitnya seperti memperluas berbagai pengetahuan masyarakat terhadap suatu ilmu yang kami bagikan.

\section{Dampak bagi masyarakat}

\section{Bidang Pendidikan}

Menurut Jervis dalam Kaswan, Akhyadi (2015) Pembelajaran adalah proses memperoleh pengetahuan, keterampilan, nilai, kepercayaan, emosi, perasaan, dan lain-lain. Singkatnya dapat dikatakan, pembelajaran merupakan proses memperoleh kompetensi. Karena kompetensi tidak lebih daripada kemampuan melakukan pada tingkat kecakapan yang disepakati, yang meliputi pengetahuan, keterampilan, sikap, dan nilai profesional.

\section{a. Bantuan Mengajar di Sekolah MI dan PAUD}

Manfaat dari bantuan mengajar ini adalah membantu meringankan tenaga dan pemikiran dari guru-guru, dan juga terjalinnya tali silahturahmi dan komunikasi antara kami, guru-guru, dan juga murid-murid.

\section{b. Bimbingan Belajar}

Manfaat dari program Bimbingan Belajar ini adalah membantu anak-anak mendapatkan cara belajar yang berbeda ketika di sekolah sehingga lebih mudah memahami pelajaran. Hal ini membuat anak-anak termotivasi untuk terus belajar karena wawasannya bertambah luas.

\section{Bidang Ekonomi}

\section{a. Celengan Kreasi}

Manfaat dari program celengan kreasi adalah meningkatnya kesadaran anak-anak akan pentingnya menabung dan juga bagaimana cara menyisihkan uang yang mereka miliki untuk ditabung.

\section{b. Kewirausahaan}

Manfaat dari program pembuatan bros dan penjualan snack adalah untuk menumbuhkan jiwa kewirausahaan agar menumbuhkan jiwa kemandirian dalam perekonomian.

\section{Bidang Hukum}

\section{a. Seminar Hukum}

Manfaat yang didapatkan dari program seminar hukum ini adalah mencegah terjadinya kenakalan remaja seperti pergaulan bebas yang dilakukan oleh anak dan juga bagaimana peran keluarga menjadi solusi bagi anak-anak yang telah terjerumus pada pergaulan yang tidak sehat. Dan dari Seminar tersebut siswa/siswi sangat antusias dan termotivasi. 


\section{Bidang Kesehatan}

\section{a. Cek Kesehatan Gratis}

Manfaat dari program cek kesehatan gratis adalah masyarakat menjadi tahu apakah terkena penyakit tidak menular sehingga mereka dapat menindaklanjuti dan juga meningkatkan kesadaran masyarakat bagaimana cara untuk mencegah suatu penyakit.

\section{b. Penyuluhan Cuci Tangan yang Baik dan Benar}

Manfaat dari Cuci Tangan yang Baik dan Benar adalah untuk mempromosikan bagaimana caranya cuci tangan yang baik dan benar dan mengetahui dampak apabila tidak mencuci tangan yang baik dan benar. Dan dapat di praktekan oleh sasaran setiap harinya.

\section{Bidang Agama Islam}

\section{a. Partisipasi dalam Majlis Ta'lim Warga}

Manfaat dari pengajian Majlis Ta'lim ini adalah mahasiswa KKN dapat menjalin silaturahmi dengan warga sehingga lebih mudah menjalin komunikasi untuk mempromosikan program kerja lainnya dan mengajak masyarakat untuk berpartisipasi dalam kegiatan mahasiswa KKN.

\section{b. Mengajar Alqur'an}

Manfaat dari program ini adalah agar anakanak TPA Desa dapat membaca Al'qur'an dengan baik dan benar dan dibarengi belajar dengan cara yang lebih menarik.

\section{c. Pengajian Rutin}

Manfaat dari program ini adalah untuk memberikan kajian islami yang dengan sasarannya yaitu santriwan santriwati pondok pesantren di sekitar desa tersebut dan santri pun menjadi lebih termotivasi untuk mengikuti pengajian.

\section{Bidang Teknik}

\section{a. Pelatihan Komputer Dasar}

Kegiatan ini bertujuan untuk memberikan pengetahuan dan ilmu tentang komputer maupun laptop yang mana meningkatkan kemampuan komputerisasi dan juga teknologi kepada anak-anak dan para remaja.

\section{b. Pembuatan Incinerator}

Pembuatan Alat ini bertujuan untuk membakar sampah organik maupun anorganik. Sisa abu pembakaran sampah organik nantinya dapat dimanfaatkan untuk kompos. Dan hasilnya banyak warga yang mudah untuk mengelola sampahnya di Desa.

\section{c. Plang Jalan}

Program kegiatan ini bertujuan untuk menambah infrastruktur yang berfungsi untuk memberikan tanda lokasi dimana telah memasuki area desa Wangunjaya. 


\section{DAFTAR PUSTAKA}

Cahyadi, A. 2019. Keutamaan Menyantuni

Anak Yatim. Diunduh dari https://ydsf.org/berita/keutamaanmenyantuni-anak-yatim-ydsfUenX.html

Chandra, B. 2009. Ilmu Kedokteran Pencegahan \& Komunitas. Penerbit Buku Kedokteran EGC : Jakarta.

Direktorat Pembinaan Penelitian dan Pemberdayaan Masyarakat. 2007. Pengetahuan dasar KKN. Universitas Indonesia : Jakarta.

Kaswan \& Akhyadi, A. S. 2015. Pengembangan Sumber Daya Manusia. Penerbit Alfabeta: Bandung.

Prasetya, E. (2018). Pemberdayaan Masyarakat Tentang Kesehatan, Pendidikan dan Kreatifitas. Abdi Dosen: Jurnal Pengabdian Pada Masyarakat 2 (1), 19-25.

Riadi, M. 2017. Tujuan, Prinsip, dan Tahapan Pemberdayaan Masyarakat. Diunduh dari https://www.kajianpustaka.com/2017 /11/tujuan-prinsip-dan-tahapanpemberdayaan-masyarakat.html

Sutrisman, D. 2019. Pendidikan Politik, Persepsi, Kepemimpinan, dan Mahasiswa. Guepedia Publisher: Bogor.

Syarifudin. 2012. Pendidikan dan pemberdayaan masyarakat. PerdanaPublis : Medan.

Lutfi, Muhamad, Dkk. 2019. Laporan Kuliah Kerja Nyata. Universitas Ibn Khaldun Bogor

Herawati, Siti. 2018. Memberdayakan Potensi Keluarga Melalui Partisipasi Dan Kesadaran Lingkungan Masyarakat Di Desa Cimanggu Ii Kecamatan Cibungbulang Kabupaten Bogor. Universitas Ibn Khaldun Bogor

Fathimah, Anissatul, Dkk. 2019. Pemberdayaan Masyarakat Melalui Peningkatan Mutu Pendidikan, Ekonomi Dan Kesehatan Studi Kasus Desa Cibeber II. Vol 3, No.1 